\title{
Educational Autonomy Of Industrial Revolution 4.0
}

\author{
Jonson Rajagukguk \\ Faculty of Fisipol Universitas HKBP Nomensen Medan \\ North Sumatra, Indonesia \\ e-mail:jonson.rguk@gmail.com
}

\begin{abstract}
Education is the only tools that can be used to build a country civilization. Human resources expected to be good through the education therefore, the good governance of education has a positive impact to the quality of education. All the time, the good governance of education in Indonesia is still far from what we expected for. It is not focused on creating excellent graduate but rather than done as a routine activity without any effort how to develop and improve our education quality. Moreover, in the era of regional autonomy, the secondary education is under the provincial and district government authority. The education autonomy that give full authority should jack up the quality of our education spontaneously because there are abundance of authority including the finance management. How does the regional government manage the education autonomy especially in industrial revolution 4.0 is a question that need to be answered by the provincial and district government nowadays.
\end{abstract}

Key words: education autonomy, industrial revolution 4.0

\section{Introduction}

In the theory of management, one of the factors of success in doing the task is delegating authority. Delegating the authority means entrust the subordinate. Entrust the subordinate is an important mindset in the process of successful management. According to Hasibuan (2007:68), delegating the authority is giving a part of task or authority from the delegator to the delegate to be done on behalf of the delegator. While Stoner (2000:434) stated delegating the authority is the formal delegation of authority and responsibility to the subordinate to finish particular activity. It is a consequence of bigger organization.

In the practice of government management in Indonesia, the concept of regional autonomy has been used for a long time. It is an attempt to accelerate the regional development process that aimed to lift up the standard of living of the regional society through the delegation of authority to the regional government. 
One of the topic to be discussed in regional autonomy is the educational autonomy. At this time, the level of elementary and secondary school is under the provincial and regional authorization. What provincial and regional government need to be prepared so the educational autonomy will be success is the task that need big innovation and creativity. Now, it is the time for them to have a roadmap to manage this educational autonomy well.

Now days, the challenges of the day are more complex and getting bigger. Now, we know the progress of the age called the era of industrial revolution 4.0. This era is the result of the system of thinking and human creation because of big advances in information technology. For whom be ready to adapt the changes, they will survive. But if not, they will be left behind. Therefore, in the context of governance management, in which the educational autonomy is a design of government policy for provincial and regional government. So, what should provincial and regional government do in order to be able to manage the education well in this industrial 4.0 era?

\section{Research Method}

Sugiyono said that the research method is important in doing research because it show us our understanding about the object of the research (Sugiyono: 2010). This research used descriptive analysis method in which the writer did the library research by elaborating kinds of related literature to give a clear description about the problem that is how the future of education in this industrial 4.0 era will be.

\section{Discussion}

The changing of paradigm through the era has made quite big change and bridgehead. Now, we are faced the industrial 4.0 as a product of the age. Even though it is just a term to describe how big the changes that we have already face are. According to Wikipedia, industrial 4.0 is the name of the newest automatic and data exchange trend in fabric technology. This term includes the cyber-physic system, internet, general and cognitive computation. But generally, the industrial revolution 4.0 is the integration between the internet worlds or keeping online with the entrepreneur world and production in an industry. It means all the production processes are supported by the internet.

From the above explanation, it can be concluded that the industrial revolution 4.0 is to challenge the businessmen or industry to maximize the role and function of the internet for developing the business include the local government (provincial and regional). 
Nowadays or government keep doing the socialization about the industrial revolution 4.0 in Indonesia. Even though, there are many challenges and barrier in its implementation, but the industrial 4.0 is something that we must face on. One of those is the internet connectivity. This is still be a big problem for our government to make all spaces to be internet accessible. Industrial Revolution 4.0 was introduced firstly in 2011 by German, and at that time had been the trending topic on World Economic Forum (WEF) 2016 in Davos, Swiss. There are some country that have had the program to support them in industrial 4.0 era such as German, England, United States of America, china, India, Japan, Korea, and Vietnam (www.warta.economi.co.id).

Industrial revolution 4.0, that has been increased rapidly, has connected us with the whole aspect of our life include to the world of education. The educational autonomy as an authority will face this era with all the consequences included in it. Before explain the educational autonomy, we need to know the regional autonomy. According to the etymology, the word autonomy come from Latin word "autos" which meant alone and "nomos" which meant rule. Therefore, it can be stated that autonomy is the own rules or to have a right/power/authority to make our own rules. Then, that meaning was turned into own government (Ubaedillah: 2014). The presence of this regional autonomy gave a new hope for regional government to be able to push the development of their own regional potential include the whole aspect except country foreign affair, defense and security, judicature, fiscal and monetary, religion, and other authority in form of wider, real and responsible autonomy. Regional autonomy that included in the law rules, substantially, showed that the region and city have an important roles in the authority and funding.

As well as the policy in developing the education, certainly, will depend on the regional policy as the part of authority that had been given through the autonomy of education management that is expected to be able to fulfill the need of society rapidly, effectively and efficiently and able to face the changing era like the industrial 4.0 today. Decentralization of education gives authority to regional government and the school that had been known as educational or school autonomy. That kind of authority gives wider space to the headmaster to manage the nature and human resources based on their own region potential.

The autonomy in the education field is not only in the level of regency/city but remain to the level of schools itself as the pioneer of the education. By doing this, therefore, the schools are expected to be able to lead their development program based on the condition and potential of each area or location. According to Umiarso and Gojali (2010) the decentralization of education design known as school based management which is the changing paradigm in managing education from central management to the management in which school is managing on their own. Firstly, school based management has been popularized on United States of America when people start questioning the relevance of education to the demands and development of the society. This management paradigm appeared when people of United State of 
America had no significant effect from the existence of educational institution where the output of education tend to stay away from social reality.

Therefore, it is an urgent thing of reformation toward the education that has supported by society and be able to give significant direct impact on it. School based management education is a new paradigm of education. It gives big authority to the school principal (society involvement) in the aspect of national education policy. The autonomy were given so that the schools are free to manage their resources and finance by allocating those based on the priority needed and more responsible to their needed. Society involvement were meant so that they have more understanding to help and control the education management.

According to Danim (2006), the policy of school based management in Indonesia were started on 1999/2000, by giving aid called as Quality Management Operational Assistance. That aid were deposited directly to the school account and not through the above educational bureaucracy.

According to Umiarso dan Gojali (2010) the Department of National Education describes that the aim of doing the school based management is to improve the quality of education through the school independence and initiative in managing and empowering their own resources; increasing the school residents and society concern in doing the education organization through making decision together; increasing schools responsibility toward parent, society, and government about the school quality; and increasing good competition among the schools about the target of education quality.

Umiarso dan Gojali stated that the basic concept of school based management is the managing the education quality empowering that done by school independently involving all related parties in education that will be called as educational or school autonomy. Therefore, in the process of planning, implementing, and evaluating school education quality will be able to involve the school stakeholder, because the essence of school based management is the school autonomy and participative decision making to reach the target of school education quality.

Thus, according to Hasbullah (2006) in education field, autonomy will empower the regional and local apparatus to give better result. In the education field, autonomy is given to the school level. School autonomy is expected to fix the service, manage school organization, look up, develop and empower the educational resources, and fix the school performance as an effort in increasing the education quality of the related school.

According to the department of national education in Sujanto (2007), there are some function that can be decentralized to school. They are: 
- Planning and evaluating school program. Related to this, the developing program can be given to the school for the sake of improvement.

- Managing curriculum. Curriculum is an important thing because it a set of material that will be taught to the students to develop the learning process. School is able to develop curriculum, but they can't reduce the content that is nationally applicable and develop by the central government. The schools are also free to develop the local content curriculum. According to Hasbullah, a good curriculum of educational institution is the curriculum of educational institution that developed by and for society or the educational institution based on the society.

- Managing the teaching learning process. An interesting learning process is a demand and necessity. Therefore, school are given the authority to build or create an interesting learning process

- Managing employment. This includes the analysis of planning necessity, recruitment planning, development, appreciation, and punishment planning, relation and evaluation of the employment can be done by school except civil servant teacher that up to this time are still handled by above bureaucracy.

- Managing equipment and supplies. The governance of school infrastructure should be done by school start from supplying, maintaining, and repairing up to the developing of the infrastructure. This is based on the fact that the school is the one that know the most the school necessity in terms of adequacy, suitability, and novelty of that necessity especially for the facilities that related closely to the learning and teaching process.

- Managing financial. This is as appropriate done by school for the special allocated fund. School must be given freedom to do more activities that will be able to give another income, therefore the financial resources will not depend only to the government.

- Student services. General Principal of service are just the same, effective and efficient. By making a good service, it is the time for the school to push the innovation of service based on the students' necessity.

- Relationship between school and society. The substance of relationship between school and society is the realization society active participation on the education unit. The society involvement as the school partner is to build students morality, in which for the example the students' parents need to push the school to be turned into qualified school. 
- Managing school atmosphere. A conducive school as the place for learning is something that must be created. Therefore, it is important to create a conducive atmosphere at school in order to get a comfortable teaching learning process.

Those nine things above are an important things to be done in the educational autonomy era nowadays. On these things, provincial and regional government need to push so the schools-those under their authority and supervision- to be developed and turned into a good one. Then what should a particular regional government do is a question that can be a motivating factor to have a successful education in this industrial $4.0 \mathrm{era}$. In this case, regional government need to do this:

- $\quad$ Giving sufficient and adequate facilities

- Doing good principal coordination

- Making workshops related to the newest education issues

- Making evaluation about weakness of the whole school area

- Involving school in planning project so the school will have same vision and mission in developing education.

Educational autonomy must be understood as a policy design that aimed to give an authority to the regional government. In this case, the regional government use their authority in order to have a good education process in their area especially in the industrial 4.0 era.

\section{Conclusion}

The educational autonomy is an important authority in education management. Managing education needs strategy, commitment and Good Corporation. In the industrial 4.0 era, the innovation and creativity are needed the most. If the school and regional government are unable to make an innovation, therefore the educational autonomy will be failed. On the other hand, a good understanding about education through the educational autonomy will make the education itself is able to answer the human resources necessity in the industrial 4.0 era.

\section{References}

Danim, Sudarwan (2006). Visi Baru Manajemen Sekolah dari Unit Birokrasi ke LembagaAkademik. Jakarta: PT Bumi Aksara. 
Hasbullah (2006). Otonomi Pendidikan: Kebijakan Otonomi Daerah Dan Implikasinya Terhadap Penyelenggaraan Pendidikan PT Raja Grafindo Persada: Jakarta.

Hasibuan, Malayu, (2010). Manajemen SDM (Sebuah pengantar), Bumi Aksara. Jakarta.

Sugiyono. (2010). Metode Penelitian Pendidikan. Bandung. Penerbit Alfateta.

Stoner, James. (2009). Manajemen, Terjemahan UI Press, Jakarta.

Sujanto, Bedjo (2007). Manajemen Pendidikan Berbasis Sekolah; Model Pengelolaaan Sekolah di Era Otonomi Daerah, Jakarta: Sagung Seto, 2007.

Ubaedillah,A.(2014):PendidikanKewarganegaraan(civicEducation).Jakarta,Kencana.

Umiarso dan Imam Ghozali (2010), Manajemen Mutu Sekolah di Era Otonomi Pendidikan, Jogjakarta.

Undang-Undang Nomor 32 Tahun 2004 tentang Pemerintahan Daerah dan Undang Undang Nomor 20 Tahun 2003 tentang Sistem Pendidikan Nasional.

Internet

www.warta.ekonomi.co.id

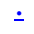



